$$
\text { M. Oristina } q_{\text {arti }}
$$

\title{
Rainwater and Throughfall Chemistry in a "Terra Firme" Rain Forest: Central Amazonia
}

\author{
M. Cristina Forti ${ }^{1}$ and L. M. Moreira-Nordemann
}

\author{
Laboratório de Pesquisas Atmosféricas e Oceânicas, Instituto Nacional de Pesquisas Espaciais \\ São José dos Campos, São Paulo, Brazil
}

\begin{abstract}
During the Global Tropospheric Experiment (GTE)-Amazon Boundary Layer Experiment (ABLE) 2B campaign in the Amazon basin, samples of rainwater and throughfall were obtained in a "terra firme" (nonflooded forest) rain forest at the Ducke Reserve $\left(2^{\circ} 57^{\prime} \mathrm{S}, 59^{\circ} 58^{\prime} \mathrm{W}\right)$. The samples were collected during one wet period (April 1 to May 13, 1987) and one dry period (August 1 to October 1 , 1987). All samples were analyzed for $\mathrm{Na}^{+}, \mathrm{K}^{+}, \mathrm{Mg}^{2+}, \mathrm{Ca}^{2+}, \mathrm{NH}_{4}^{+}, \mathrm{Cl}^{-}$and $\mathrm{SO}_{4}^{2-}$, and $p \mathrm{H}$. The rainwater was acidic, with a volume-weighted mean $p \mathrm{H}$ of 4.6 for the two periods. Rainwater input from the dry period was 2 times greater for $\mathrm{Na}^{+}, \mathrm{Mg}^{2+}, \mathrm{NH}_{4}^{+}$and $\mathrm{SO}_{4}^{2-}$ and about 4 times greater for $\mathrm{K}^{+}$than from the wet period. The ionic concentrations in throughfall were higher than those in rainwater, except for $\mathrm{NH}_{4}^{+}$during the dry period. This enrichment of throughfall is attributed to the interaction of precipitation with the forest canopy.
\end{abstract}

\section{INTRODUCTION}

The tropical rain forest has a large biomass per unit area, a greater variety of species compared to other forests, and vigorous biological activity that usually takes place throughout the year. Nevertheless, Nye and Greenland [1960] have shown that the luxuriant and tall tropical rain forest may grow on relatively nutrient poor, highly weathered substrates. Tropical rain forests have evolved mechanisms to efficiently utilize the nutrients in the soil solution, as well as those entering the forest from the atmosphere [Golley, 1983]. Nutrient distribution and cycling occur through the rainwater, mineral weathering and absorption/liberation of gases (including biological fixation) that depend mostly on climate, species composition, successional state and soil fertility [Forti, 1989].

The rainwater and throughfall chemistry in Central Amazonia have been studied by several authors [e.g., Nortcliff and Thornes, 1978; Franken and Leopoldo, 1984; Franken et al., 1985; Brinkmann, 1985; Moreira-Nordemann et al., 1986; Andreae and Andreae, 1988]. Most of these studies, however, consider only cations $\left(\mathrm{Na}^{+}, \mathrm{K}^{+}, \mathrm{Mg}^{2+}\right.$ and $\left.\mathrm{Ca}^{2+}\right)$ or only anions $\left(\mathrm{Cl}^{-}\right.$and $\left.\mathrm{SO}_{4}^{2-}\right)$. There is a lack of studies where cations and anions are studied at the same time and place.

This work is part of the Global Tropospheric Experiment (GTE)-Amazon Boundary Layer (ABLE) [Harriss et al., 1990] conducted during the wet (April-May) and dry (August-September) seasons of 1987 . For each period a continuous record of rainwater and throughfall composition and amount, was obtained in a "terra firme" rain forest ecosystem, in Central Amazonia. The results of this study focus on the interaction of precipitation with the forest canopy (the throughfall), showing a seasonal and spatial variation of the ionic input by rainwater and throughfall.

\footnotetext{
${ }^{1}$ Now at Institute of Hydrology, Wallingford, Oxon, England.

Copyright 1991 by the American Geophysical Union.
}

Paper number 90JD02170.

0148-0227/91/90JD-02170\$05.00

\section{Experimental Site}

Precipitation samples were collected at the Ducke Reserve $\left(02^{\circ} 57^{\prime} \mathrm{S}, 59^{\circ} 57^{\prime} \mathrm{W}\right)$, a 10,000 -ha preserve near Manaus. Figure 1 shows a location map of the experimental site, situated in the "Barreiras" formation. Soils are mainly yellow latosols with small areas of podzolization, and the vegetation is typical of an undisturbed, natural Amazonian "terra firme" rain forest. A detailed description of this region can be found in the works by Livingston et al. [1988] and Forti [1989].

Samples were obtained at two stations (Figure 1): the first one in a clear-cut area of approximately 0.5 ha in the Barro Branco catchment area [Franken and Leopoldo, 1984] and the second one, $2 \mathrm{~km}$ away, close to a micrometeorological tower [Fitzjarrald et al., 1988].

\section{Collection}

Samples were obtained with a collector composed of a polyethylene funnel (collecting area of $712 \mathrm{~cm}^{2}$ ), covered with a nylon screen (mesh $\sim 2 \mathrm{~mm}$ ), connected to a $2-\mathrm{L}$ polyethylene bottle.

One collector was installed at the $43 \mathrm{~m}$ elevation on the 45-m-tall micrometeorological tower, and held away from the tower by a spar, in order to prevent the collection of rain splatter from the tower. During the April-May (wet) 1987 period, the samples from the tower corresponded to the bulk precipitation because the dry deposition over the collector could not be avoided; during the August-September (dry) 1987 period, this collector was washed daily with $2 \mathrm{~L}$ of deionized water to minimize the dry deposition.

The throughfall samples were collected near the tower where fifteen different points were selected over a $100-\mathrm{m}$ transect. Over these points, five collector pairs were set up, approximately $1 \mathrm{~m}$ above the ground (the screens were daily changed), and their positions were changed randomly each 20 days.

Another pair of collectors was installed in a clearing $(0.5$ ha), close to the "Barro Branco igarape," $1 \mathrm{~m}$ above the ground and $20 \mathrm{~m}$ from the forest edge. Their screens were changed daily. 


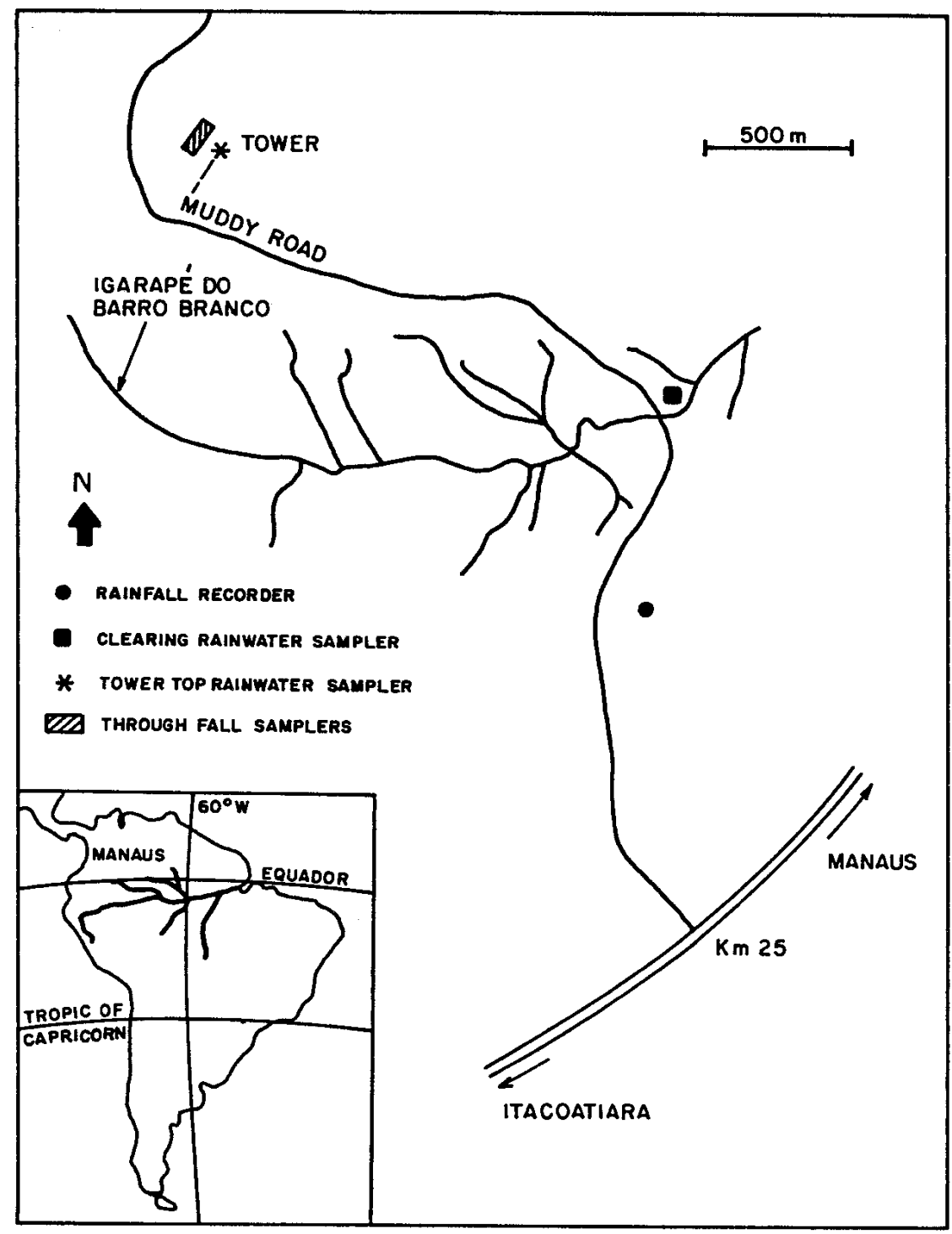

Fig. 1. Localization map of sampling sites in Ducke Reserve, near Manaus.

The rainwater samples were collected every 24 hours, one event being considered as the total rainfall precipitated during this time interval; all the precipitation events that occurred during the collection periods were collected.

After the collection, the samples were preserved, to prevent algae growth, with prewashed chloroform (1\% in volume) to eliminate $\mathrm{Cl}^{-}$ions that might be present in the chloroform, and then sent to the Instituto de Pesquisas Espaciais (INPE) in São José dos Campos, São Paulo, Brazil, and stored at $4^{\circ} \mathrm{C}$.

During the wet period (April 1 to May 13), 16 samples were collected at the tower; 18 pairs in the clearing (for the period April 1 to May 13) and 16 sets of throughfall samples (totaling 80 sample pairs) were taken. During the dry period (August 1 to October 1), 10 samples were collected at the tower, 11 pairs at the clearing and 10 sets of throughfall samples were taken (totaling 50 pairs).

For all samples, the $p \mathrm{H}$ was measured on the collecting day, utilizing a Digimed field $p \mathrm{H}$ meter with a combined plastic electrode, having an internal reference system of $\mathrm{Ag} / \mathrm{AgCl}$. The $\mathrm{NH}_{4}^{+}$ion was analyzed by potentiometry, with an Orion (model 811) electrode with $\mathrm{NH}_{3}$ internal solution, and the readings were performed in June and
October, for the samples collected during the wet and dry period, respectively. Storage tests during a six month period showed that the $\mathrm{NH}_{4}^{+}$ion remained stable for this length of time (differences $<10 \%$ ). The cations, $\mathrm{Na}^{+}, \mathrm{K}^{+}, \mathrm{Mg}^{2+}$ and $\mathrm{Ca}^{2+}$, were analyzed by atomic absorption spectrometry, with Varian AA 1475 equipment [Thompson and Reynolds, 1978]. The samples collected during the wet period were analyzed in July 1987 . One half of them were reanalyzed in January 1988, together with the samples from the dry season. Finally, in May 1988, all samples were reanalyzed. The results from the three analyzed sets $(\sim 5 \%)$ did not show significant differences. Ion chromatography, using EPA method [Pfaff, 1986], was used to quantify the anions $\mathrm{Cl}^{-}$ and $\mathrm{SO}_{4}^{2-}$. The first nine samples collected at the tower were analyzed in Manaus in May 1987. In December 1987, the same samples and those collected from the clearing were analyzed in Centro de Pesquisas de Aguas Subterraneas, University of São Paulo (CEPAS/USP) laboratory. Finally, these samples, together with the remaining ones, were analyzed at INPE's laboratory during February 1989. The $\mathrm{Cl}^{-}$and $\mathrm{SO}_{4}^{2-}$ concentrations did not change significantly with time, giving the same values for the means, although the mean $\mathrm{NO}_{3}^{-}$values decreased. The volumetric weighted 
TABLE 1. Rainwater and Throughfall $\mathrm{NO}_{3}^{-}$During the Wet and Dry Periods

\begin{tabular}{lcccccc}
\hline & \multicolumn{2}{c}{ Rainwater } & & \multicolumn{2}{c}{ Throughfall } \\
\cline { 2 - 3 } \cline { 6 - 7 } & Wet & Dry & & Wet & Dry \\
\hline Volumetric weighted mean & 6.5 & 6.4 & & 14.1 & 8.7 \\
Standard deviation & 10.2 & 6.5 & & 32.4 & 9.0 \\
Maximum & 56.4 & 19.0 & & 242 & 29.3 \\
Minimum & 0 & 0 & & 0 & 0 \\
\hline
\end{tabular}

Values are in micromoles of $\mathrm{NO}_{3}^{-}$per liter.

means, standard deviations and maximum and minimum values for $\mathrm{NO}_{3}^{-}$are presented in Table 1 , to provide some indication of its importance in these samples.

Blanks of the deionized water as well as of the containers and screens were analyzed. The results for the analyzed ions were below the detection limit, obtained from the calibration curves, of the various methods. The blanks of deionized water with $1 \%$ chloroform, without the prewashed chloroform, showed $1 \mu \mathrm{mol} \mathrm{Cl}^{-} / \mathrm{L}$, a result not detected with prewashing.

The screen which covered the tower collector during the wet period was taken out to analyze the soluble deposited material. The total mass deposited was obtained by gravimetry. The screen was immersed in $100 \mathrm{~mL}$ of deionized water and submitted to ultrasound for $30 \mathrm{~min}$; the aqueous solution was taken out, filtered in a $4-\mu \mathrm{m}$ porous Millipore filter and stored for later analysis.

The volume of each sample was measured with an accuracy of $10 \%$. These values were used to calculate the volume weighted mean for the ionic content, and the mean $p \mathrm{H}$ was obtained from the volumetric weighted mean of the calculated $\mathrm{H}^{+}$concentrations.

\section{Results AND Discussion}

\section{The Rainwater $p H$}

The rainwater $p \mathrm{H}$ varied between 4.0 and 5.3, with a volume weighted mean of $4.6 \pm 0.1$ for the wet period and $4.5 \pm 0.1$ for the dry period. Other authors obtained similar $p \mathrm{H}$ values for different tropical rain forests (Table 2). The acidity of rainwater observed in this study is in accordance with current results, which indicate that the rainwater is acidic with values between 4.5 and 5.0 [Rodhe et al., 1988] in tropical rain forests.

TABLE 2. Rainwater $p \mathrm{H}$ Values for Some Tropical Rain Forests

\begin{tabular}{|c|c|c|c|}
\hline \multirow[b]{2}{*}{ Locale } & \multicolumn{2}{|c|}{$p \mathbf{H}$} & \multirow[b]{2}{*}{ Reference } \\
\hline & Mean & Range & \\
\hline Amazonia & 5.1 & $4.7-5.7$ & Stallard and Edmond [1981] \\
\hline Venezuela & 4.6 & $3.8-6.2$ & Steinhardt and Fassbender [1979] \\
\hline Venezuela & 4.8 & $4.4-5.2$ & Galloway et al. [1982] \\
\hline Costa Rica & 5.3 & $4.8-6.3$ & Hendry et al. [1984] \\
\hline Trinidad & 5.8 & $5.3-6.4$ & McDowell [1988] \\
\hline Australia & 4.8 & $4.2-5.4$ & Galloway et al. [1982] \\
\hline Amazonia & 4.7 & $4.0-5.3$ & this work \\
\hline
\end{tabular}

\section{Above the Canopy Versus the Clearing Rainwater Chemical Composition}

The mean ionic concentration of the rainwater samples collected above the canopy (tower collection) and from the clearing indicated different results, in spite of being only 2 $\mathrm{km}$ apart. Table 3 presents the volumetric weighted means, mean standard deviations, superior and inferior confidence intervals of $5 \%$, in micromoles per liter, and sampled volumes, obtained for the two sites during the wet and dry periods.

Part of the observed differences between the mean ionic concentrations in the rainwater samples above the canopy and the clearing is due to the dry deposition in the tower collector, mainly during the wet period, when only bulk precipitation samples were obtained. The analyses of the aqueous solution of the screen which covered the tower collector, during the wet period, presented the following values: $0.75 \mu \mathrm{g} \mathrm{Na}^{+} / \mathrm{g}, 0.95 \mu \mathrm{g} \mathrm{K}^{+} / \mathrm{g}, 0.08 \mu \mathrm{g} \mathrm{Mg}^{2+} / \mathrm{g}, 0.33$ $\mu \mathrm{g} \mathrm{Ca}^{2+} / \mathrm{g}, 1.30 \mu \mathrm{g} \mathrm{NH}{ }_{4}^{+} / \mathrm{g}, 1.20 \mu \mathrm{g} \mathrm{Cl}^{-} / \mathrm{g}$, and $17.65 \mu \mathrm{g}$ $\mathrm{SO}_{4}^{2-} / \mathrm{g}$. The total mass deposited was $103 \mu \mathrm{g}$, indicating that the amount of dry deposition was not negligible. However, the dry deposition cannot be considered as the main factor which determined the composition differences found in the two sampled locations. For example, during the dry period, when the dry deposition was minimized, the difference between the mean values of the concentrations remained. Another potential source of this observed difference is differences in the sampled volumes [Lloyd and Marques, 1988]; however, these did not occur (see Table 3).

According to Brinkmann [1985], the roughness of the forest canopy surface generates vortices due to turbulent flow, even at low speed winds. Raupach et al. [1980] studied the effect of the turbulent flux on rough closed canopies, showing that gradient measurements over these surfaces must be done above the level

$$
Z=h+1.5 d
$$

where $h$ and $d$ are the height and the transverse length scale of the roughness elements, respectively. Measurements need to be made above this height $(Z)$ to minimize the effects of the roughness sublayer, a region where significant vertical transport of momentum, and consequently, mass occur. Viswanadham et al. [1990] estimated a $Z$ value of $39 \mathrm{~m}$, for the tower region; as the collector was at $43 \mathrm{~m}$ height, there was a high probability of its being in the interior of the roughness sublayer (Y. Viswanadham, personal communication, 1989). The washout effect of this roughness sublayer by rainfall could be the main cause of the enrichment of the samples collected from the tower, in relation to those collected in the clearing. Due to this effect, the rainwater samples collected in the clearing will be considered in this work as representative of the atmospheric input by rainwater.

\section{The Rainfall Ionic Input}

Figure 2 presents mean monthly rainfall (in millimeters), measured in Ducke Reserve for the years 1966-1988 and the monthly rainfall during 1987 . For the months of April and May, the rainfall was $35 \%$ lower in relation to the long time averages, while for August and September 1987, it was $32 \%$ higher. We also observe that the total rainfall for the wet 
TABLE 3. Volumetric Weighted Mean Values, Mean Standard Deviations, 5\% Confidence Intervals, and Total Sampled Volumes for the Tower and Clearing Samples for the Wet and Dry Periods

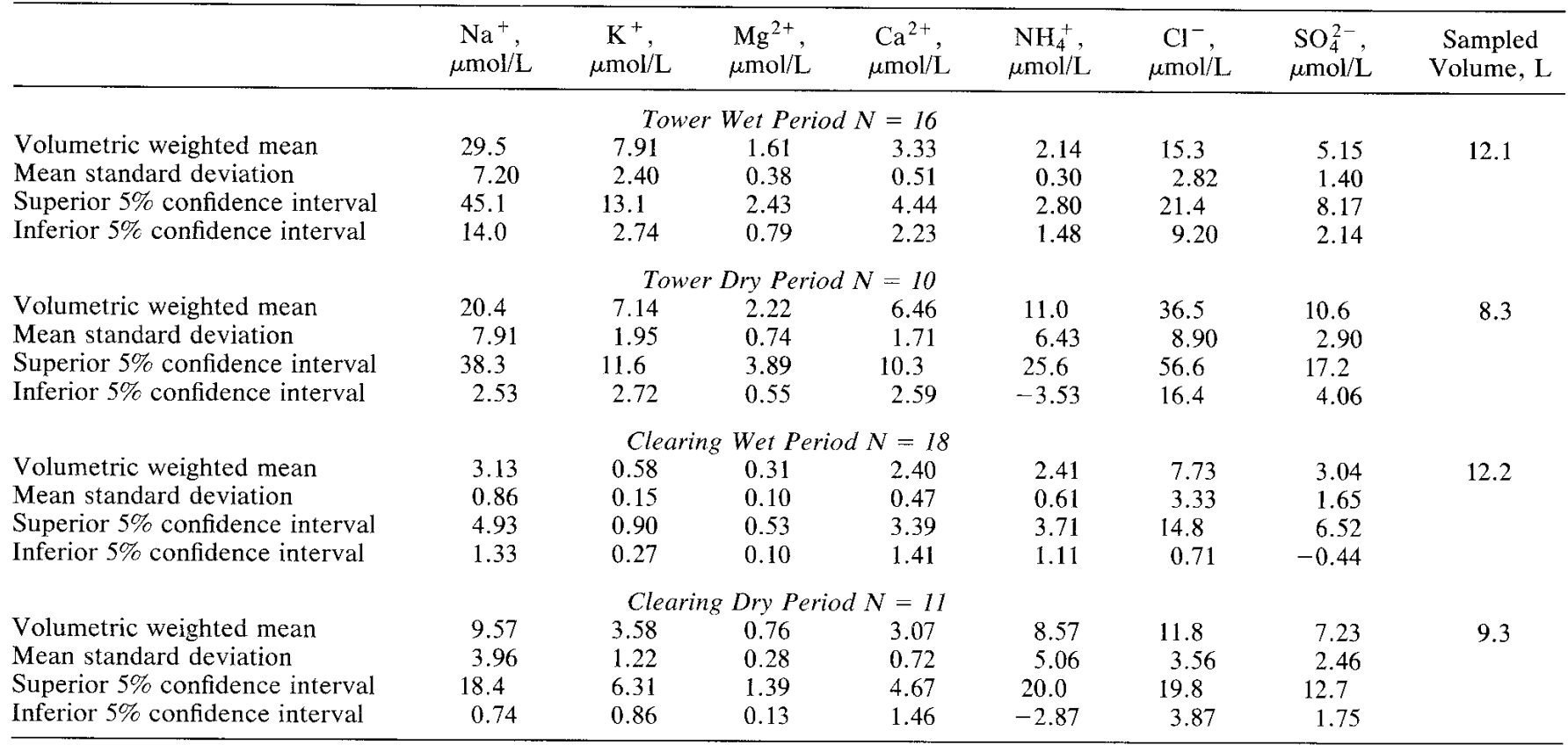

$N$ denotes sample number.

period $(379 \mathrm{~mm})$ was not much higher than for the corresponding value for the dry period $(261 \mathrm{~mm})$. Therefore, the periods covered by this work do not have characteristic rainfall, when compared to the long-term mean values.

Rainfall input of the elements in kilograms per hectare for the two periods is seen in Table 4. These results show that during the dry period, the inputs of $\mathrm{Na}^{+}, \mathrm{Mg}^{2+}, \mathrm{NH}_{4}^{+}$and $\mathrm{SO}_{4}^{2-}$ are approximately twice as great as for the wet period; the input of $\mathrm{K}^{+}$is 4 times that of the wet period and the inputs of $\mathrm{Ca}^{2+}$ and $\mathrm{Cl}^{-}$are equivalent for both periods.

In an experiment conducted in the same place during 1977 , Franken et al. [1985] observed that the fluxes of these elements were higher during the rainy season than during the dry one. Similar results were obtained by Lewis [1981] in a study conducted at Lake Valencia in 1977. However, two important points must be considered when comparing these results: (1) the rainfall in the Ducke Reserve in April-May 1977, was $659 \mathrm{~mm}$, while it was $379 \mathrm{~mm}$ in 1987; and during August-September 1977, it was $188.9 \mathrm{~mm}$ against $261.2 \mathrm{~mm}$ in 1987; and (2) the forest burnings were less intense in 1977. During the dry season in 1987 , the number and extent of the fires were extensive [Setzer et al., 1988].

The $\mathrm{Na}^{+}, \mathrm{K}^{+}, \mathrm{Mg}^{2+}, \mathrm{NH}_{4}^{+}$and $\mathrm{SO}_{4}^{2-}$ ions have higher inputs during the dry period. The deposition by rainfall

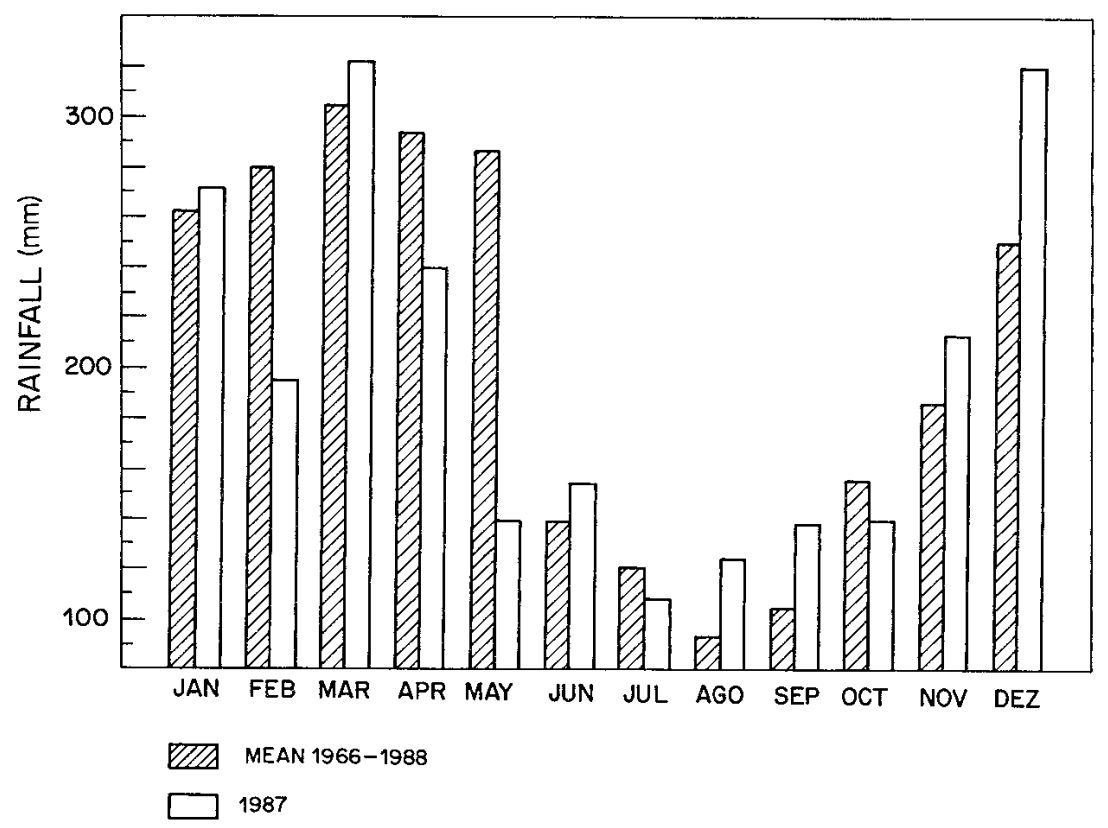

Fig. 2. Mean monthly pluviometric values for $1966-1988$ and 1987 for the Ducke Reserve. 
TABLE 4. Ecosystem Input by Rainwater for the Wet and Dry Periods

\begin{tabular}{lccccccc}
\hline & $\mathrm{Na}^{+}$ & $\mathrm{K}^{+}$ & $\mathrm{Mg}^{2+}$ & $\mathrm{Ca}^{2+}$ & $\mathrm{NH}_{4}^{+}$ & $\mathrm{Cl}^{-}$ & $\mathrm{SO}_{4}^{2-}$ \\
\hline Wet & 0.25 & 0.07 & 0.02 & 0.30 & 0.15 & 0.86 & 0.91 \\
Dry & 0.49 & 0.31 & 0.04 & 0.28 & 0.34 & 0.93 & 1.54 \\
\hline
\end{tabular}

Values are in kilograms per hectare.

through the washout depends on the soluble aerosol residence time, washed component solubility, rainfall regime and the quantity of the injected aerosols in the atmosphere [Junge, 1963]. As a consequence, measurements on a short time scale are more susceptible to these variations, getting larger fluxes, mostly during the dry season, when the rainfall intervals are larger and an increase of the aerosols in the atmosphere (e.g., by the fires) takes place.

The $\mathrm{Ca}^{2+}$ inputs are equivalent for the two periods. We expected the $\mathrm{Ca}^{2+}$ input to be similar to the other ions but during the wet period the input was smaller. However, another $\mathrm{Ca}^{2+}$ source is the soil, but the soils of this region are depleted in soluble cations [Stark, 1971]. Talbot et al. [1990] discuss a similar behavior for the soluble aerosols in this region, suggesting that they are introduced in the Central Amazon region, through air masses coming from Central Brazil and the northern hemisphere.

\section{The Throughfall Ionic Input}

The quality of precipitation falling on the forest is altered during a brief but significant interaction with the surfaces of the plants, resulting in a transfer of additional mineral matter to the forest floor. Throughfall and stemflow are the major pathways in the nutrient recycling. As stemflow transfers only 5-20\% of the total nutrients in rainwater [Brinkmann and dos Santos, 1971], it was not considered in this work.

Table 5 shows the volumetric weighted means, mean standard deviations, superior and inferior confidence intervals of $5 \%$ and the ionic input in kilograms per hectare by the throughfall. These values are expressed in net content, defined as the amount of nutrients added to the precipitation as it passes through the canopy, during the two studied periods. By this process it can be observed that all the elements are enriched in the throughfall, except the $\mathrm{NH}_{4}^{+}$; this ion seems to be absorbed in the dry period. The small return or even absorption of $\mathrm{NH}_{4}^{+}$may be attributed to the foliar absorption by the microflora and other populations usually existing on the leaves, trunk and branches [Franken et al., 1985].

In Table 5 the percent values of the ratio $(R / T)$ of the ions transported by rainwater $(R)$ to the throughfall $(T)$ are also shown. It can be noticed that the $R / T$ ratios for $\mathrm{Na}^{+}$and $\mathrm{Mg}^{2+}$ are equivalent during the two periods; for $\mathrm{K}^{+}$it is higher during the dry period; in contrast $\mathrm{Ca}^{2+}, \mathrm{Cl}^{-}$and $\mathrm{SO}_{4}^{2-} R / T$ ratios are smaller during this same period.

The ionic return in throughfall has the following sequence: $\mathrm{Mg}^{2+}>\mathrm{K}^{+}>\mathrm{Na}^{+}>\mathrm{Ca}^{2+}>\mathrm{NH}_{4}^{+}>\mathrm{SO}_{4}^{2-}>\mathrm{Cl}^{-}$(wet) and $\mathrm{Mg}^{2+}>\mathrm{K}^{+}>\mathrm{Ca}^{2+} \sim \mathrm{Na}^{+}>\mathrm{Cl}^{-}>\mathrm{SO}_{4}^{2-}$ (dry).

The throughfall is a very important source of $\mathrm{Mg}$ and $\mathrm{K}$ for the soil. Of the total ionic input reaching the soil, only about $10 \%$ comes from rainwater, the difference being added to precipitation as it passes through the canopy. These elements, according to Vitousek and Sanford [1986], participate in the forest internal recycling.

The $R / T$ ratio for $\mathrm{Na}^{+}$is equal for the two periods. Because higher $\mathrm{Na}^{+}$quantities enter the ecosystem by rainwater, during the dry period, the $\mathrm{Na}^{+}$is being transferred in larger quantities from the vegetation to the throughfall during this period. Franken et al. [1985] found evidence of the $\mathrm{Na}$ absorption during the periods of high rainfall (wet season), relating the $\mathrm{Na}$ absorption and elimination in different periods of the year to metabolic processes of some plants and, based on the $\mathrm{Na} / \mathrm{K}$ ratio, they also suggested that a substitution of $\mathrm{K}$ by $\mathrm{Na}$ in the system may be occurring.

The $\mathrm{Ca}^{2+}$ species is the smallest contributor to this enrichment process during the two periods. For example, during the dry period the leaching is even smaller. This transference pattern is found in different tropical forest systems, particularly in those with lower fertility soils [Vitousek and Sanford, 1986], where the $\mathrm{Ca}^{2+}$ values in tree leaves are relatively low.

Of the quantity of $\mathrm{Cl}^{-}$reaching the soil by the throughfall, our results show that the major fraction is introduced by rainwater, in the two periods, with a higher enrichment during the dry period. Similar findings were obtained by Franken et al. [1985]. They attributed this greater amount of

TABLE 5. Throughfall Volumetric Weighted Means, Mean Standard Deviation, 5\% Confidence Intervals, Ionic Inputs and Rainwater/ Throughfall Ratio $(R / T)$ for the Wet and Dry Periods

\begin{tabular}{|c|c|c|c|c|c|c|c|}
\hline & $\mathrm{Na}^{+}$ & $\mathrm{K}^{+}$ & $\mathrm{Mg}^{2+}$ & $\mathrm{Ca}^{2+}$ & $\mathrm{NH}_{4}^{+}$ & $\mathrm{Cl}^{-}$ & $\mathrm{SO}_{4}^{2-}$ \\
\hline \multicolumn{8}{|c|}{ Wet Period, $N=75$} \\
\hline Volumetric weighted mean & 10.6 & 6.64 & 3.65 & 5.10 & 4.65 & 10.3 & 4.64 \\
\hline Mean standard deviation & 0.99 & 0.72 & 0.42 & 0.55 & 0.70 & 0.91 & 0.042 \\
\hline Superior $5 \%$ confidence interval & 12.6 & 8.07 & 4.49 & 6.20 & 6.05 & 12.1 & 5.49 \\
\hline Inferior $5 \%$ confidence interval & 8.60 & 5.21 & 2.82 & 3.99 & 3.24 & 8.48 & 3.80 \\
\hline Input, kg/ha & 0.45 & 0.67 & 0.24 & 0.29 & 0.08 & 0.19 & 0.36 \\
\hline$R / T, \%$ & 36 & 10 & 8 & 51 & 65 & 82 & 72 \\
\hline \multicolumn{8}{|c|}{ Dry Period, $N=48$} \\
\hline Volumetric weighted mean & 29.6 & 25.1 & 10.9 & 10.2 & 6.14 & 21.0 & 11.8 \\
\hline Mean standard deviation & 2.66 & 2.27 & 0.87 & 0.96 & 1.17 & 1.84 & 0.80 \\
\hline Superior $5 \%$ confidence interval & 35.9 & 29.6 & 12.6 & 12.1 & 9.49 & 24.7 & 13.4 \\
\hline Inferior $5 \%$ confidence interval & 24.2 & 20.5 & 9.13 & 8.24 & 3.79 & 17.3 & 10.2 \\
\hline Input, $\mathrm{kg} / \mathrm{ha}$ & 0.88 & 1.67 & 0.50 & 0.55 & -0.12 & 0.57 & 0.75 \\
\hline$R / T, \%$ & 36 & 16 & 8 & 34 & 155 & 62 & 67 \\
\hline
\end{tabular}

$N$ denotes number of samples. 
TABLE 6. Ionic Content in the Aqueous Solution of the Deposited Material Over the Screen During the Wet Period and Its Contribution to the Ionic Content in Throughfall

\begin{tabular}{llllllll}
\hline & $\mathrm{Na}^{+}$ & $\mathrm{K}^{+}$ & $\mathrm{Mg}^{2+}$ & $\mathrm{Ca}^{2+}$ & $\mathrm{NH}_{4}^{+}$ & $\mathrm{Cl}^{-}$ & $\mathrm{SO}_{4}^{2-}$ \\
\hline Ionic content, $\mathrm{kg} / \mathrm{ha}$ & 0.01 & 0.01 & 0.002 & 0.05 & 0.02 & 0.02 & 0.26 \\
Contribution to throughfall, $\%$ & 4 & 3 & 2 & 28 & 29 & 13 & 100 \\
\hline
\end{tabular}

$\mathrm{Cl}^{-}$in throughfall to its elimination by the predehiscent leaves, that occur mostly during the dry season.

The major fraction of the $\mathrm{SO}_{4}^{2-}$ ion in throughfall is from rainwater for both periods. Sulphur is an essential element for the vegetation and it might have been washed from the vegetation in its $\mathrm{SO}_{4}^{2-}$ form, thus enriching the throughfall.

The particulate deposition over the canopy, however, must be considered, and this elemental source may be a significant component of the throughfall. Gosz et al. [1983], (cited by Vose [1985]) suggested that the canopy can provide much more nutrient input from the atmosphere than that measured normally by bulk precipitation analysis, and McColl [1978] noticed that particulates impacted on the vegetation could supply 2 to 3 times greater inputs for certain ions than did rainfall.

From the analysis of aqueous solutions of the deposited material over the screen, the throughfall component due to the washout of soluble material deposited on the vegetation for the wet period was estimated [Parker, 1983]. The estimated values are presented in Table 6 . These results suggest that during the wet period, the main component of throughfall for $\mathrm{Na}^{+}, \mathrm{K}^{+}, \mathrm{Mg}^{2+}$ and $\mathrm{Cl}^{-}$was the leaching of these ions from the vegetation; for $\mathrm{Ca}^{2+}$ and $\mathrm{NH}_{4}^{+}$the leaching may be an important process and for $\mathrm{SO}_{4}^{2-}$ the component due to the washout of impacted particulate on the leaves predominates over that due to the leaching.

\section{CONCLUSIONS}

As found in other tropical rain forests, the rainwater in Central Amazonia is acidic, with a volume-weighted mean $p \mathrm{H}$, of 4.6 , for the two periods studied (dry and wet seasons). The rainwater samples collected above the canopy are enriched in relation to those collected from a clearing, probably due to the washing of aerosols from the roughness sublayer above the forest canopy.

The throughfall ionic content is enriched in relation to the rainwater due to the interaction with the vegetation. The major elements transferred from the vegetation to the throughfall for the two periods are: $\mathrm{Mg}^{2+}$ and $\mathrm{K}^{+}(90 \%)$, $\mathrm{Na}^{+}(70 \%), \mathrm{Ca}^{2+}(60 \%), \mathrm{Cl}^{-}(25-40 \%)$ and $\mathrm{SO}_{4}^{2-}(40 \%)$. It is possible to observe $\mathrm{NH}_{4}^{+}$absorption by the vegetation during the dry period. It may be inferred that during the wet period, the main source of $\mathrm{Na}^{+}, \mathrm{K}^{+}, \mathrm{Mg}^{2+}$ and $\mathrm{Cl}^{-}$in the throughfall is from the leaching of the vegetation, in contrast to the $\mathrm{SO}_{4}^{2-}$ ion whose main source could be from the washing of the impacted particulate material from the vegetation.

Acknowledgments. The authors wish to thank W. Franken from Instituto de Pesquisas da Amazonia (INPA) for his invaluable support during the field campaign, A. C. Rebouças and A. A. Kimmelmann who permitted us to use the CEPAS/USP laboratory, L. C. B. Molion for his cooperation under difficult and somewhat unusual conditions, our staff members O. M. Danelon, C. M.
Espírito Santo and D. D. Sardela, and the financial support from GTE/ABLE and the partial support from FINEP (Financiadora de Estudos e Projetos, Brazil).

\section{REFERENCES}

Andreae, M. O., and T. W. Andreae, The cycle of biogenic sulfur compounds over the Amazon Basin, 1, Dry season, J. Geophys. Res., 93, 1487-1497, 1988.

Brinkmann, W. L. F., Studies on hydrobiogeochemistry of a tropical lowland forest system, GeoJournal, 11(1), 89-101, 1985.

Brinkmann, W. L. F., and A. dos Santos, Natural waters in Amazonia, V, Soluble magnesium properties, Turrialba, 21(4), $459-465,1971$

Fitzjarrald, D. R., B. L. Stormwind, G. Fish, and O. M. R. Cabral, Turbulent transport observed just above the Amazon forest, $J$. Geophys. Res., 93(D2), 1551-1563, 1988.

Forti, M. C., Hidroquímica das soluçōes na interface atmosfera-solo num ecossistema de terra firme (Amazônia Central), Ph.D. thesis, 151 pp., Inst. Astron. e Geofís., Univ. de São Paulo, Brazil, Dec. 1989.

Franken, W., and P. R. Leopoldo, Hydrology of catchment areas of Central-Amazonia forest, in The Amazon, edited by $\mathrm{H}$. Sioli, pp. 501-519, W. Junk Publishers, Dordrecht, Netherlands, 1984.

Franken, W., P. R. Leopoldo, and H. Bergamin, Nutrient flow through natural waters in "terra firme" forest in Central Amazon, Turrialba, 35(4), 383-393, 1985.

Galloway, J. N., G. E. Likens, W. C. Keene, and J. M. Miller, The composition of precipitation in remote areas of the world, $J$. Geophys. Res., 87(11), 8771-8786, 1982.

Golley, F. B., Nutrient cycling and nutrient conservation, in Tropical Rainforest Ecosystems, pp, 137-156, chap. 9, Elsevier Science, New York, 1983.

Gosz, J. R., D. G. Brookins, and D. I. Moore, Using strontium isotope ratios to estimate inputs to ecosystems, Bioscience, 33(1), $23-30,1983$.

Harriss, R. C., et al., The Amazon boundary layer experiment: Wet season 1987, J. Geophys. Res., 95, 16,721-16,736, 1990.

Hendry, D. C., C. W. Berish, and E. S. Edgerton, Precipitation chemistry at Turrialba, Costa Rica, Water Resour. Res., 20(11), $1677-1684,1984$

Junge, C. E., Chemistry of precipitation, in Air Chemistry and Radioactivity, Int. Geophys. Ser., vol. 4, pp. 289-311, chap. 4, Academic, San Diego, Calif., 1963.

Lewis, W. M., Jr., Precipitation chemistry and nutrient loading by precipitation in a tropical watershed, Water Resour. Res., I7(1), $169-181,1981$.

Livingston, G. P., P. M. Vitousek, and P. A. Matson, Nitrous oxide flux and nitrogen transformations across a landscape gradient in Amazonia, J. Geophys. Res., 93(D2), 1593-1599, 1988.

Lloyd, C. R., and A. de O. Marques, Spatial variability of throughfall and stemflow measurements in Amazonian rainforest, Agric. For. Meteorol., 42, 63-73, 1988.

McColl, J. G., Ionic composition of forest soil solution and effects of clear cutting, Soil Sci. Soc. Am. J., 42, 358-363, 1978.

McDowell, W. H., Potential effects of acid deposition on tropical terrestrial ecosystem, in Acidification in Tropical Countries, edited by $\mathrm{H}$. Rodhe and R. Herrera, chap. 4, John Wiley, New York, 1988.

Moreira-Nordemann, L. M., M. C. Forti, and C. M. Espirito Santo, Rain water chemistry of Central Amazonia (dry season 1985), Rep. INPE-4063-PRE/I021, Inst. de Pesquis. Espaciais, São José dos Campos, Sao Paulo, Brazil, 1986.

Nortcliff, S., and J. B. Thornes, Water and cation movement in a tropical rainforest environment, 1, Objectives, experimental de- 
sign and preliminary results, Acta Amazonica, 8(2), 245-258, 1978.

Nye, P. H., and D. J. Greenland, The soil under shifting cultivation, Tech. Commun. 52, 156 pp., Commonwealth Bur. of Soils, Harpenden, England, 1960.

Parker, G. G., Throughfall and stemflow in the forest nutrient cycle, Adv. Ecol. Res., 13, 57-133, 1983.

Pfaff, J. D., Chloride, orthophosphate, nitrate and sulfate in wet deposition by chemically supressed ion chromatography, Method 300.6, Environ. Prot. Agency, Washington, D. C., 1986.

Raupach, M. R., A. S. Thom, and I. Edwards, A wind tunnel study of turbulent flow close to regularly arrayed rough sourfaces, Boundary Layer Meteorol., 18(4), 373-397, 1980.

Rodhe, H., E. Cowling, I. E. Galbaly, J. N. Galloway, and R. Herrera, Acidification and regional air pollution in the tropics, Acidification in Tropical Countries, edited by H. Rodhe and R. Herrera, pp. 3-39, John Wiley, New York, 1988.

Setzer, A. W., M. C. Pereira, A. C. Pereira, Jr., and S. A. O. Almeida, Relatório de atividades do projeto IBDF-INPE "SEQE"-Ano 1987, Rep. INPE-4534-RPE/565, Inst. de Pesquis. Espaciais, São José dos Campos, Sao Paulo, Brazil, 1988.

Stallard, R. F., and J. M. Edmond, Geochemistry of the Amazon, 1, Precipitation chemistry and the marine contribution to the dissolved load at the time of peak discharge, J. Geophys. Res., 86(C10), 9844-9858, 1981.

Stark, N., Nutrient cycling, 1, Nutrient distribution in some Amazonian soils, Trop. Ecol., 12(1), 24-50, 1971.

Steinhardt, V., and H. W. Fassbender, Caracteristicas y composition química de las lluvias de los Andes occidentales de Venezuela, Turrialba, 29(3), 175-182, 1979.

Talbot, R. W., M. O. Andreae, H. Berresheim, P. Artaxo, M.
Garstang, R. C. Harriss, K. M. Beecher, and S. M. Li, Aerosol chemistry during the wet season in Central Amazonia: The influence of long-range transport, J. Geophys. Res., 95, 16,955$16,969,1990$

Thompson, K. C., and R. J. Reynolds, Atomic Absorption, Fluorescence and Flame Spectroscopy: A Practical Approach, Charles Griffin, London, 1978.

Viswanadham, Y., L. C. B. Molion, A. O. Manzi, L. D. A. Sa, V. P. Silva Filho, R. G. B. André, J. L. M. Nogueira, and R. C. dos Santos, Micrometeorological measurements in Amazon forest during GTE/ABLE 2A mission. J. Geophys. Res., 95, 13,669$13,682,1990$.

Vitousek, P. M., and R. L. Sanford, Jr., Nutrient cycling in moist tropical forest, Annu. Rev. Ecol. Syst., 17, 137-167, 1986.

Vose, P. B., A preliminary attempt to evaluate sulphur mass balance and cycle in the Amazon Basin, paper presented at Workshop on Biogeochemistry of Tropical Rainforest: Problems for Research, WWF-US/D-LPF/USP/CENA Piracicaba, São Paulo, Brazil. 1985.

M. C. Forti, Institute of Hydrology, Maclean Building, Wallingford, Oxon OX10 8BB, England.

L. M. Moreira-Nordemann, Laboratório de Pesquisas Atmosféricas e Oceânicas, Instituto Nacional de Pesquisas Espaciais, C. P. 515, São José dos Campos, São Paulo, 12201 Brazil.

(Received May 12, 1989; revised October 1, 1990; accepted October 1, 1990.) 